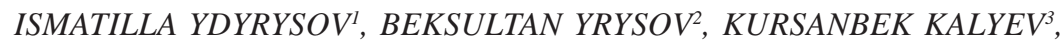
KENESHBEK YRYSOV ${ }^{4}$ (Bishkek, Kyrgyz Republic)

\title{
GENERAL DESCRIPTION OF ORGANIZING SPECIAL CARE IN SEVERE COMBINED TRAUMATIC BRAIN INJURY IN OSH REGION OF KYRGYZ REPUBLIC
}

\author{
${ }^{1}$ Osh State University, Department of General Surgery, Osh, Kyrgyz Republic; \\ ${ }^{2}$ Kyrgyz State Medical Academy, Neurosurgery Department, Bishkek, Kyrgyz Republic; \\ ${ }^{3}$ Osh Interregional Integrated Clinical Hospital, Osh, Kyrgyz Republic; ${ }^{4}$ Nagoya University Graduate \\ School of Medicine, Young Leader's Program, Nagoya, Japan <kenexbek@yahoo.com>
}

\begin{abstract}
The article deals with the general description of severe combined traumatic brain injury and organizing special neurosurgical care to patients in Osh Region of Kyrgyz Republic. Material and methods: Among the patients mainly man are dominated - $77.9 \%$, and man at the age of 20 to $50(69.9 \%)$, i.e. the most able-bodied part of the society. Results: The main cause of severe combined traumatic brain injury is still a traffic accident (74.3\%). Postsurgical and overall mortality in clinics where there is no full-time neurosurgeon and computed tomography scanner is higher. Most hospitals in Osh Region are still not equipped with computer tomography. The presence in the hospital staff full time neurosurgeon has crucial importance in reducing postsurgical and overall mortality.
\end{abstract}

Key words: severe combined traumatic brain injury; risk factors; prognosis for outcomes.

Introduction. Combined traumatic brain injury is the most common kind of all multisystem traumas. Combined injuries are not a simple combination of traumatic injuries of different organs. Such traumas range from 43 to $68 \%$ of cases, and in combined traumas, brain injuries are prevailing. This - is a special category of injury in which the pathological process has its own characteristics and regulations $[3,6,14]$. Scientific interest in the combined injury increased particularly in the last 10-15 years, it is due to a significant increase of lethality compared with the isolated trauma and increase of number of patients. Thus, according to some authors, lethality in an isolated TBI varies within $1-3 \%$, and in combined TBI from 20.4 to $35 \%$. In developed Western countries in the eighties of the last century there have been significant changes in the understanding of pathophysiology and treatment of severe TBI which has led to a reduction of lethality in severe combined traumatic injury (SCTBI) from 80-90 to 30$40 \%[5,17,20]$. The rate of lethality was reduced approximately by $10 \%$ every 10 years during the last three decades of the twentieth century, mainly due to the improvement of the organization of the aid to patients with SCTBI and wide use of standards by the patients of this category. In Kyrgyz Republic the lethality in SCTBI is still as high as $80 \%$ [7]. In very severe combined trauma of musculoskeletal system, chest, abdomen with damaged parenchymatous organs (heart, lungs, liver, spleen), especially with the subsequent massive bleeding, traumatic brain injury lethality reaches 90-100\% $[4,9,16]$. In the developed countries of Europe and the USA the main reason of SCTBI is still remains a traffic injury which is from 50 to $70 \%$, so its prevention acquires national significance. Shortcomings which were detected as a result of investigation allow improving the aid to patients with SCTBI at all stages. Development of scientifically grounded measures to improve the neurosurgical service is impossible without studying the epidemiology of SCTBI. In Osh Region it was adopted concept 
of closest approach of specialized aid to the population through the establishment of neurosurgical department on the basis of regional and city hospitals. There were deployed two neurosurgical departments in Osh Region.

Material and methods. Study population. It was studied main epidemiological indexes of severe combined traumatic brain injury of Osh Region of Kyrgyz Republic over the period of 2015 to 2018. Sources of Information about all cases of SCTBI were materials of medical records of hospitals: medical cards of inpatients, statistical card of discharged patient, statistical coupons of ambulance. To study epidemiological aspects of SCTBI and providing medical care to patients, a scheme of analysis of information has developed. Totally it was studied 136 cards of inpatients with SCTBI, and selection and analysis was carried out only in cases where the diagnosis was confirmed by a complex of clinical, X-Ray and morphological methods of study.

General characteristics of series

\begin{tabular}{lccc}
\hline \multicolumn{1}{c}{ Data } & Number (\%) & P value \\
\hline \hline Total number of patients & $136(100 \%)$ & 0.491 \\
Traffic accident & $101(74.3 \%)$ & 0.372 \\
Household trauma & $21(15.4 \%)$ & 0.129 \\
Catatrauma & $13(9.6 \%)$ & 0.183 \\
Men & $106(77.9 \%)$ & 0.306 \\
Women & $30(22.1 \%)$ & 0.294 \\
20-50 years old & $95(69.9 \%)$ & 0.287 \\
Traumatic shock & $116(85.3 \%)$ & 0.312 \\
Closed TBI & $73(53.7 \%)$ & 0.265 \\
Neurosurgical operations & 44 & \\
Subdural hematoma & $23(52.3 \%)$ & 0.183 \\
Epidural hematoma & $6(13.6 \%)$ & 0.207 \\
Depressed skull fracture & $15(34.1 \%)$ & 0.491 \\
Within the first 12 hours & $36(81.8 \%)$ & 0.189 \\
Surgical activity & $31.6 \%$ & \\
\hline
\end{tabular}

Results. During the period from 2015 to 2018 there were 136 patients with SCTBI were hospitalized in Osh Region of Kyrgyz Republic. The main reason of SCTBI was traffic accident - $101(74.3 \%)$.

Household injuries were verified in $21(15.4 \%)$ patients, catatrauma - in $13(9.6 \%)$ patients. Most of patients were men -106 (77.9\%). At the age of 20 to 50 were 95 (69.9\%) patients of all patients (table).

Pre-hospital stage. The first hour after trauma is called "golden hour" so far as the condition of the patients can be improved by skillful actions to support the breath and blood circulation in the pre-hospital stage. The main objectives at pre-hospital stage are adequate assessment of the severity of the victim, first aid and fast delivery of the patients and as much as possible delivery of patients to the specialized medical institution. As another points out, within the first "golden" hour only $56.6 \%$ of patients are taken to the hospital. Most of patients with SCTBI in the studied groups were taken to hospital within the first two hours. Within the first so called "golden hour" 28 patients $(20.6 \%)$ has been taken to hospitals. In the interval from 1 to 2 hours after trauma 20 $(14.7 \%)$ patients were taken to hospital respectively.

Hospital stage. Majority of patients with SCTBI in the studied group were taken to the hospital with the symptoms of traumatic shock - 116 patients $(85.3 \%)$ ).In hospital patient strategy management remains unchanged but additional methods of inspection are added and measures which were taken at the occurrence location will be received. Traumatic shock of the $3^{\text {rd }}$ and $4^{\text {th }}$ degree that has major clinical significance was verified in $66(48.5 \%)$ patients. 
In the structure of severe traumatic brain injury was mainly dominated a closed TBI - 73 patients $(53.7 \%)$. While analyzing the type of combined damages at SCTBI it was found that multiply injuries have been prevailed (i.e. severe TBI and injury of two or more systems of the body) - 38 (27.9\%) patients, the combination of severe TBI and thoracic trauma - $13(9.6 \%)$ patients. In district hospitals neurosurgeon consulted 31 patients with SCTBI $(22.8 \%)$, and it is due to the fact that patients were hospitalized at night, on holidays and weekends, when there was no full time neurosurgeon. In this case specialized service provided duty traumatologist and neurologist. On the subject of severe TBI it was performed 44 surgeries, $23(52.3 \%)$ of which - removal of acute subdural hematoma, $6(13.6 \%)$ surgeries - removal of epidural hematoma, 15 surgeries $(34.1 \%)$ - the primary surgical treatment of the depressed fracture of the cranial bones and application of diagnostic burr-holes, and 36 surgeries $(81.8 \%)$ are done within the first 12 hours. Surgical activity is $31.6 \%$ respectively.

Discussion. In any review on TBI the authors divide the whole period of existence of neurotraumatology into pre-computer and post computer era. Computed tomography and magnetic resonance image of the brain - are the methods of choice in diagnosis of traumatic brain injury [15]. Only 46 patients $(33.8 \%)$ received CT/MRI before the operation. MRI is located in another building or on the territory of other institutions (for example, in Osh City Magnetic Resonance Image machine is installed in the Regional Children's Hospital), as a result transporting of the infirm patients is associated with a great technical difficulties. It should be noted that in the majority of magnetic resonance rooms there is no artificial breathe apparatus, but as far as majority of patients need constant ventilation of lungs, then it makes impossible to carry out studies. As a result the hospitals with MRI virtually every fifth patient gets diagnostic burr holes in order to eliminate traumatic intracranial hematoma.

The frequency of lethal termination in the pre-hospital stage directly depends on the quality of the first aid. In Western countries due to the improvement of pre-hospital aid the percentage of lethality in SCTBI at pre-hospital stage in recent years was successfully reduced up to $7 \%[1,10]$. According to some authors, immediately up to $50 \%$ of all deaths from severe combined and multiply trauma are lost at the occurrence location, another $30 \%$ die due to the transportation to the hospital.

It is necessary to emphasize the importance of traumatic shock in the pathogenesis and lethality at multisystem trauma. If shock is developed in $28-61 \%$ of patients in the combined trauma, then $80 \%$ of patients in SCTBI $[2,8]$ that is certainly requires an early start of antishock measures at the pre-hospital stage.

Thus, postsurgical lethality is $62.8 \%$. Total lethality is fixed to $61.8 \%$. High postsurgical lethality at a sufficient high surgical activity can be explained by the lack of neurosurgeon, and a later date of the emergency surgical interventions at TBI inevitably negatively affects the results of treatment. Conducted by calculating goodness of fit (compliance) x 2 analysis with probability of $95 \%$ required in conducting such studies found significant differences in the timing of surgery in hospitals with the presence of a neurosurgeon in the state and do not have any. Lethality is one of the most important indicators of a hospital $[11,12]$.

Analysis of the causes of the death in patients with SCTBI specified that leading position is occupied by shock and blood loss (differentiation of these concepts in clinical and foreskin practice is almost impossible). Thus, due to the above reasons $42.3 \%$ of the patients were died. High lethality from shock and blood loss can be explained by the fact that among the patients was found the greatest number of patients with multiply injuries $38(27.9 \%)$ and with the symptoms of traumatic shock of the $3^{\text {rd }}$ and $4^{\text {th }}$ degrees at admission $66(48.5 \%)$. Brain swelling and its dislocation, as well as pneumonia and tracheobronchitis $(42.5 \%)$ are in the first place among the causes of death $[13,18]$. 
Thus, treatment of patients with combined and multiply trauma is one of the vital problems of medical science and health care service, and clinical practice shows the success of health care service to these patients at pre-hospital and hospital stages in many ways depends not only on medical but also on the organizational activities which determine the timeliness of the ongoing therapy. Time factor, skill of the physician, the algorithm of his actions, available medical instrumentation and medical provision are of crucial importance here [19].

Conclusion. During the first "golden" hour after trauma only $20.4 \%$ of all patients with SCTBI are taken to the hospital and it indicates the lack of effective work of emergency service, and $48.7 \%$ of hospitalized patients are in a state of traumatic shock. The main cause of severe combined traumatic brain injury is still traffic injuries (70$79 \%)$, the prevention of it acquires the national significance. Among the patients dominate mainly man $106(77.9 \%)$, whose age from 20 to $50-95(69.9 \%)$, i. e. the most capable of active working part of the society.

The presence neurosurgeon in the medical institution as well as a computer and magnetic resonance image or only neurosurgeon allows significantly reduce postsurgical and general lethality in patients with SCTBI comparing to other clinics and as a result significantly reduce economic losses that are brought to the country, which is 2 to $10 \%$ of GDP in different countries.

The presence in the staff the full time neurosurgeon in the hospital but not computed tomography has the crucial importance in reducing the postsurgical and total lethality; therefore first of all it is necessary to develop neurosurgical service in region. Most hospitals in Osh region are still not equipped with computed tomography, and the majority of operating units are in twenty-four-hour service. As a rule there is no ALV apparatus in computed tomography office and it doesn't allow carrying out investigation with the patients with SCTBI who need constant ventilation of lungs.

Acknowledgements. Authors were permitted to use the data of patients of Osh Interregional Integrated Clinical Hospital in Osh of Kyrgyz Republic to conduct research and to publish their results in any scientific journals.

Conflict of interests. There is no conflict of interests to disclose for each author.

\section{References}

1. Becker D. P., Miller J. D., Ward J. D. et al. The outcome from severe head injury with early diagnosis and intensive management // J. Neurosurg. - 1977. - Vol. 47. - P. 491-502.

2. Brain Trauma Foundation; American Association of Neurological Surgeons; Joint Section on Neurotrauma and Critical Care. Guidelines for the management of severe head injury // J. Neurotrauma. - 1996. - Vol. 13. - P. 641-734.

3. Broos P. L., D'Hoore A., Vanderschot P. Multiple trauma in patients of 65 and over. Injury patterns. Factors influencing outcome. The importance of an aggressive care // Acta Chir. Belg. 2013. - Vol. 93. - P. 126-130.

4. Bulloek R. Management and Prognosis of Severe Traumatic Brain Injury. - Vashington: Brain Trauma Foundation (c), 2012. - $286 \mathrm{p}$.

5. Carney N. A., Ghajar J. Guidelines for the management of severe traumatic brain injury. Introduction // J. Neurotrauma. - 2007. - Vol. 24 (Suppl. 1). - P. 1-2.

6. Dereeper E., Ciardelli R., Vincent J. L. Fatal outcome after polytrauma: multiple organ failure or cerebral damage? // Resuscitation. - 2013. - Vol. 36. - P. 15-18.

7. Firsching R. Classification of severe head injury based on magnetic resonance imaging // Acta Neurochir (Wien). - 2001. - Vol. 143. - P. 263-271.

8. Haselsberger K., Pucher R., Auer L. M. Prognosis after acute subdural or epidural hemorrhage // Acta Neurochir. (Wien). - 1988. - Vol. 90. - P. 111-116.

9. Hatashita S., Koga N., Hosaka Y. et al. Acute subdural hematoma : severity of injury, surgical intervention, and mortality // Neurol. Med. Chir. (Tokyo). - 1993. - Vol. 33. - P. 13-18.

10. Jennett B., Bond M. Assessment of outcome after severe brain damage // Lancet. - 1975. Vol. 1. - P. 480-484.

11. Klun B., Fettich M. Factors influencing the outcome in acute subdural hematoma. A review of 330 cases // Acta Neurochir. (Wien). - 1984. - Vol. 71. - P. 171-178. 
12. Koc R. K., Akdemir H., Oktem I. S. et al. Acute subdural hematoma: outcome and outcome prediction // Neurosurg. Rev. - 1997. - Vol. 20. - P. 239-244.

13. Kotwica Z., Brzezinski J. Acute subdural hematoma in adults: an analysis of outcome in comatose patients // Acta Neurochir. (Wien). - 1993. - Vol. 121. - P. 95-99.

14. Langlois J. A., Rutland-Brown W., Wald M. M. The epidemiology and impact of traumatic brain injury: a brief overview // J. Head. Trauma Rehabil. - 2006. - Vol. 21. - P. 375-378.

15. Lobato R. D., Cordobes F., Rivas J. J. et al. Outcome from severe head injury related to the type of intracranial lesion. A computerized tomography study // J. Neurosurg. - 1983. - Vol. 59. P. 762-774.

16. Marshall L. F., Gautille T., Klauber M. R. The outcome of severe closed head injury // J. Neurosurg. - 1991. - Vol. 75. - P. 528-536.

17. Narayan R. K., Michel M. E., Ansell B. et al. Clinical trials in head injury // J. Neurotrauma. 2002. - Vol. 19. - P. 503-557.

18. Seelig J. M., Becker D. P., Miller J. D. et al. Traumatic acute subdural hematoma: major mortality reduction in comatose patients treated within four hours // New. Engl. J. Med. - 1981. Vol. 304. - P. 1511-1518.

19. Shigemori M., Syojima K., Nakayama K. et al. The outcome from acute subdural hematoma following decompressive hemicraniectomy // Acta Neurochir. (Wien). - 1980. - Vol. 54 - P. 61-69.

20. Tagliaferri F., Compagnone C., Korsic M. et al. A systematic review of brain injury epidemiology in Europe // Acta Neurochir. (Wien). - 2006. - Vol. 148. - P. 255-268.

\title{
ЗАГАЛЬНА ХАРАКТЕРИСТИКА ОРГАНІЗАЦІЇ СПЕЦІАЛІЗОВАНОЇ ДОПОМОГИ ПРИ ТЯЖКІЙ ПОЄДНАНІЙ ЧЕРЕПНО-МОЗКОВІЙ ТРАВМІ В ОШСЬКІЙ ОБЛАСТІ КИРГИЗСЬКОЇ РЕСПУБЛІКИ
}

\section{I. Т. Идирисов, Б. К. Ирисов, К. М. Калиєв, К. Б. Ирисов}

(Бишкек, Киргизська Республіка)

Описано загальну характеристику тяжкої поєднаної черепно-мозкової травми і організація спеціалізованої нейрохірургічної допомоги потерпілим в Ошській області Киргизськой Республіки. Серед потерпілих більшість становили чоловіки - 77,9 \% у віці від 20 до 50 років $(69,9$ \%). Головною причиною тяжкої поєднаної черепно-мозкової травми, як і раніше, був дорожньо-транспортний травматизм (74,3\%). Післяопераційна і загальна летальність в клініці, в якій немає штатного нейрохірурга і комп'ютерного томографа, значно вища. Більшість стаціонарів Ошськой області не оснащена комп'ютерними томографами. Отже, вирішальне значення для зниження післяопераційної і загальної летальності має наявність в штаті стаціонару постійно працюючого нейрохірурга.

Ключові слова: тяжка поєднана черепно-мозкова травма; чинники ризику; прогноз результатів.

\section{ОБЩАЯ ХАРАКТЕРИСТИКА ОРГАНИЗАЦИИ СПЕЦИАЛИЗИРОВАННОЙ ПОМОЩИ ПРИ ТЯЖЁЛОЙ СОЧЕТАННОЙ ЧЕРЕПНО-МОЗГОВОЙ ТРАВМЕ В ОШСКОЙ ОБЛАСТИ КЫРГЫЗСКОЙ РЕСПУБЛИКИ}

\author{
И. Т. ЫІыирысов, Б. К. Ырысов, К. М. Кальев, К. Б. Ырысов
}

(Бишкек, Кыргызская Республика)

Описана общая характеристика тяжёлой сочетанной черепно-мозговой травмы и организация специализированной нейрохирургической помощи пострадавшим в Ошской области Кыргызской Республики. Среди пострадавших в основном преобладали мужчины - 77,9 \%, в возрасте от 20 до 50 лет $(69,9 \%)$. Основной причиной тяжёлой сочетанной черепно-мозговой травмы по-прежнему был дорожно-транспортный травматизм (74,3%). Послеоперационная и общая летальность в клинике, в которой нет штатного нейрохирурга и компьютерного томографа, значительно выше. Большинство стационаров Ошской области не оснащены компьютерными томографами. Итак, решающее значение для снижения послеоперационной и общей летальности имеет наличие в штате стационара постоянно работающего нейрохирурга.

Ключевые слова: тяжёлая сочетанная черепно-мозговая травма; факторы риска; прогноз исходов. 